\title{
Phytochemical Screening, Antibacterial Activity, and Mode of Action on Morus nigra
}

\author{
Diah Lia Aulifa*1, Sani Nurlaela Fitriansyah'1, Seno Aulia Ardiansyah², Diki Prayugo Wibowo", \\ Yolanda Armiliani Julata', Desty Santi Christy'
}

\section{Diah Lia Aulifa*1, Sani Nurlaela Fitriansyah', Seno Aulia Ardiansyah², Diki Prayugo Wibowo', Yolanda Armiliani Julata', Desty Santi Christy ${ }^{1}$}

\section{'Department of Pharmaceutical Biology, Sekolah Tinggi Farmasi Indonesia (Indonesian School of Pharmacy), Jl. Soekarno-Hatta No 354, Bandung 40266, West Java, INDONESIA. ${ }^{2}$ Department of Pharmacology, Sekolah Tinggi Farmasi Indonesia (Indonesian School of Pharmacy), Jl. Soekarno- Hatta No 354, Bandung 40266, West Java, INDONESIA. \\ Correspondence \\ Diah Lia Aulifa \\ Department of Pharmaceutical Biology, Sekolah Tinggi Farmasi Indonesia (Indonesian School of Pharmacy), JI. Soekarno-Hatta No 354, Bandung 40266, West Java, INDONESIA. \\ Telp./Faks. 022-7566484 \\ E-mail: diahliaaulifa@gmail.com}

\section{History}

- Submission Date: 20-10-2017;

- Review completed: 13-11-2017;

- Accepted Date: 21-11-2017

\section{DOI : 10.5530/pj.2018.1.28}

Article Available online

http://www.phcogj.com/v10/i1

\section{Copyright}

(c) 2018 Phcog.Net. This is an openaccess article distributed under the terms of the Creative Commons Attribution 4.0 International license.

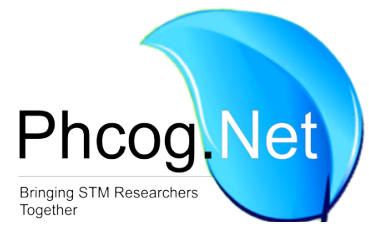

\begin{abstract}
Introduction: The Morus nigra (Moraceae) known as black mulberry is a well-grown plant in Lembang, Indonesia. Previous studies showed that black mulberry fruit has activity as antibacterial and antioxidant. The aims of this study were to evaluate the antibacterial effect of ethanol extract from stem bark, fruit, and leaves of Morus nigra, MIC and morphological changes of the most active extract against Staphylococcus epidermidis and Propionibacterium acnes. Methods: Agar diffusion and microdilution assays were used to evaluate the antibacterial effect of the extract by measuring the zone of inhibition and the minimum inhibitory concentration $(\mathrm{MIC})$ of the extract against the test bacteria. Scanning electron microscopy (SEM) was performed to evaluate the morphological changes induced by the extract in cellular membrane of the bacteria. Protein and ion leakage from the bacterial cells induced by the extract were also evaluated. Results: The antibacterial activity showed the most active extract was an ethanol extract of the stem bark against $S$. epidermidis and P. acnes with MIC value $4 \mathrm{mg} / \mathrm{ml}$ and $2 \mathrm{mg} / \mathrm{ml}$, respectively. The extract also induced protein and ion leakage in test bacterial cells. SEM findings revealed that the extract induced potential cellular membrane damage in $4 \times \mathrm{xMIC}$. Conclusion: The antibacterial activity was related to the damaged of bacterial cell wall.

Key words: Morus nigra, Staphylococcus epidermidis, Propionibacterium acnes, Cellular membrane damage.
\end{abstract}

\section{INTRODUCTION}

In a few decades, many antibiotics were found to be resistance. ${ }^{1}$ This has led to search for new, safe and effective antibacterial agents for natural plants. ${ }^{2}$ Indonesia have so many biodiversity, one of the plant that belong to family Moraceae, Morus nigra or known as black mulberry, a plant native to China and nowdays cultivated in several countries, including Indonesia. The fruit is purplish red and has sweet flavor. There are several compounds that have been studied on Morus nigra L, such as fenol, flavonoid (kuwanon E and kuwanon $\mathrm{U}$, and morusin), chalcone, 1-deoxynojirimycin. $^{3,4,5,6}$

Empirically in China, black mulberry plants are often used to decrease blood pressure, anti-hyperglycemic, diuretic, antioxidant, anthelmintic, anti-parasitic and inhibit bacterial i.e. Bacillus subtilis, Micrococus flavus, Streptococcus faecal, Staphylococcus aureus, Eschericia coli, and Pseudomonas aeruginosa. ${ }^{4,10}$ Previous studies showed that the ethanol extract of Morus nigra fruit has activity against Propionibacterium acnes (MIC $2.5 \%$ ) and Staphylococcus epidermidis (MIC $2.5 \%$ ). ${ }^{11}$ Acne vulgaris is the most common skin desease. Staphylococcus aureus, Staphylococcus epidermidis, and Propionibacterium acnes were proliferate during puberty and can developed acne. ${ }^{1,12}$ antibacterial. ${ }^{67,8,9}$ Black mulberry was known could
The Antibacterial method should be posibble for extracts, fractions and isolates. Its method should be simple, rapid, reproducible, and inexpensive..$^{13}$ One of the most commonly used for antibacterial activity methods are diffusion and dilution method. This research will reported the antibacterial activity and mode of action on Morus nigra.

\section{MATERIALS AND METHODS}

\section{General experimental apparatus}

The tools used are: maceration equipment, Incubator (Jenaco), autoclave (My Life), spectrophotometer UV-Vis (Shimadzu UV-VIS 1800), Atomic Absorption Spectroscopy (Shimadzu), Scanning Electron Microscope (SEM) (JEOL JSM-5310LV), ion coater (Ion Coater IB2 ${ }^{\circ}$ ).

\section{MATERIALS}

Black Mulberry (Morus nigra) obtained from the mulberry Plantation field in Bandung, Indonesia and authenticated in Herbarium Bandungense, Bandung Institute of Technology, Indonesia. The samples were dried in drying cabinet $\left(40-50{ }^{\circ} \mathrm{C}\right)$, and cut into fine pieces.
Cite this article: Aulifa DL, Fitriansyah SN, Ardiansyah SA, Wibowo DP, Julata YA, Christy DS Phytochemical Screening, Antibacterial Activity, and Mode of Action on Morus nigra. Pharmacog J. 2018;10(1):167-71. 


\section{Determination of Antibacterial activity}

\section{Microorganisms used}

Staphylococcus epidermidis (S. epidermidis) and Propionibacterium acnes (P. acnes) were obtained from the collection of Microbiology Laboratory, Faculty of Pharmacy, Universitas Padjadjaran.

\section{Culture media Bacterial inoculum}

S. epidermidis and P. acnes were maintained on Muller Hinton Agar (MHA) (Merck) Petri dish sterile for $24 \mathrm{~h}$ at $37^{\circ} \mathrm{C}$. The turbidity of the resulting suspensions was diluted with sodium chloride $0.9 \% \mathrm{w} / \mathrm{v}$ to obtain a transmittance of $25.0 \%$ at $580 \mathrm{~nm}$. The percentage was compared to McFarland turbidity standard using UV Spectrophotometry (Shimadzu ). The level of turbidity is equivalent to approximately $3.0 \mathrm{x}$ $10^{8} \mathrm{CFU} / \mathrm{ml}$.

\section{Phytochemical Analysis}

To determine the content of secondary metabolites contained in black mulberry (Morus nigra) is carried out phytochemical screening is test of alkaloids, flavonoids, tannins, polyphenols, monoterpenes, sesquiterpenes, steroids, triterpenoids, quinones, saponins. ${ }^{14}$

\section{Extraction}

Dried black mulberry stem bark, fruit, and leaves (@200 g; 2 litre) was extracted by maceration method using ethanol as solvent for $3 \times 24 \mathrm{~h}$, then concentrated to dryness under vacuum at temperature $45^{\circ} \mathrm{C}$ by using rotary evaporator (IKA) $)$.

\section{Antibacterial Activity}

The antibacterial activity was performed using Agar Diffusion method on ethanol extract of stem bark, fruit, and leaves of black mulberry. $150 \mu \mathrm{l}$ bacterial suspension was added into $15 \mathrm{ml}$ of medium and homogenized, then incubated at $37^{\circ} \mathrm{C}$ for $24 \mathrm{~h}$. The extract was dissolved in $1 \% \mathrm{v} / \mathrm{v}$ DMSO to obtain four concentrations: $50 ; 25 ; 12.5$ and $6.25 \% \mathrm{w} / \mathrm{v}$. Clindamycin $(50 \mu \mathrm{l})$ was used as positive control and $1 \% \mathrm{v} / \mathrm{v}$ of Dimethyl sulfoxide (DMSO) solution was used as negative control. The antibacterial activity was experimented in triplicate, and the mean value was also determined. ${ }^{12}$

\section{Minimum inhibitory concentration (MIC) evaluation}

MIC was determined by a micro-dilution method using a microplate. $100 \mu \mathrm{l}$ MHB media added into $100 \mu \mathrm{l}$ of extract. Furthermore, each well was added $10 \mu \mathrm{l}$ of the bacterial suspension was adjusted to McFarland turbidity standards was equivalent to approximately $3.0 \times 10^{8} \mathrm{CFU} / \mathrm{ml}$. Furthermore, the microplate was covered with a plastic wrap and then incubated at $37^{\circ} \mathrm{C}$ for $24 \mathrm{~h}^{15}$

\section{Cell Morphological Observation}

Clear zone derived from the treatment in the antibacterial test soaked with a solution of $2 \%$ glutaraldehyde overnight. Test solution is centrifuged and the supernatant discarded. The residue was added to a solution of $2 \%$ tannic acid, then soaked a few h. Test solution was centrifuged back and disposed of fixative solution was then added chocodylate buffer, and soaked for $20 \mathrm{~min}$. Test solution centrifuged and the supernatant is separated, then added $1 \%$ osmium tetraoxide and soaked for 1 hour. The test solution was centrifuged and the supernatant discarded and soak together $50 \%$ alcohol for $20 \mathrm{~min}$. The residue is dried in a row with alcohol 70\%, 80\%, 95\% and absolute alcohol for 20 min each. Samples were suspended with the addition of buthanol and soaked $20 \mathrm{~min}$, then the suspension placed on the cover slip, dried with a freeze dryer and then coated with gold and observed using Scanning Electron Microscopy (SEM) (JEOL JSM-5310LV*). ${ }^{16,17}$

\section{Analysis of Protein and Nucleic Acid Leakage}

The bacterial suspension that has been grown for $24 \mathrm{~h}$ in $10 \mathrm{~mL}$ Mueler Hinton Borth (MHB) medium was taken and centrifuged at 3500 RPM for $20 \mathrm{~m}$. The filtrate was discarded and the pellets in the tube were washed with phosphate buffer ( $\mathrm{pH} 7.0$ ) solution for 2 times, then suspended in $10 \mathrm{ml}$ of phosphate buffer ( $\mathrm{pH} \mathrm{7.0)}$ solution and shaken for $24 \mathrm{~h}$. Furthermore, the black mulberry stem bark extract was added with concentration of $1 \mathrm{xMIC}, 2 \mathrm{xMIC}$, and control into suspension. Suspension is centrifuged at $3500 \mathrm{RPM}$ for $15 \mathrm{~min}$, and then filtered in order to separate the supernatant and cells. Supernatant fluids were taken and measured their absorbance at wavelengths of $260 \mathrm{~nm}$ and $280 \mathrm{~nm}$ using UV/VIS spectrophotometry (Shimadzu UV-VIS 1800).

\section{Analysis of lon Leakage}

Ion leakage analysis is performed on prepared bacterial pellets such as on leakage of proteins and nucleic acids. Leakage of cells is expressed by measurements of ions $\left(\mathrm{Ca}^{2+}\right.$ and $\left.\mathrm{K}^{+}\right)$present in test bacteria after contact with $4 \mathrm{xMIC}$ concentrations. The leakage of $\mathrm{Ca}^{2+}$ and $\mathrm{K}^{+}$ions is measured using AAS (Shimadzu). ${ }^{18}$

\section{RESULTS AND DISCUSSION}

The phytochemical screening was done to the crude drug, ethanol extract of stem bark, fruit, and leaves Table 1. The essential oil of monoterpene and sesquiterpen were absence on leave. Morus nigra belongs to Genus Morus known rich in phenolic such as kuwanon $\mathrm{E}$ and kuwanon $\mathrm{U}$, chalcone, morusin, moracin, anthocyanin, vanillic acid hexoside, 5-p-Ocoumaroylquinic acid, 4,5-di-O-caffeoylquinic acid, luteolin hexoside, luteolin rutinoside, and quercetin rhamnosyl dihexoside. ${ }^{19,20,21}$

Among three extracts that were investigated for antibacterial activity, two extracts including stem bark and fruit ethanol extract had an inhibitory effect against $S$. epidermidis and $P$. acnes, but had moderate activity on leaves ethanol extract of black mulberry (Graphic 1). Diffusion method was chosen because this method was simple, rapid, reproducible, and inexpensive. ${ }^{13}$ This diffusion method is not recommended for natural water-insoluble antimicrobial compounds, such as steroid, terpenoid and essential oil. The hydrophobic nature of the natural compound prevents uniform diffusion through the agar medium. ${ }^{22}$ In this study, the substances used to suspense the extract were DMSO 1\% as solvent. After being suspended, the extracts could diffused in the media, and inhibited the growth of bacterial.

The minimum inhibitory was continued on stem bark ethanol extract due to the stable inhibitory Figure 1 against $S$. epidermidis and $P$. acnes with MIC value $4 \mathrm{mg} / \mathrm{ml}$ and $2 \mathrm{mg} / \mathrm{ml}$. To observe a morphological alteration after the cell was treated with the most active extract, stem bark ethanol extract, against $P$. acnes, a bacterial specific caused acnes by using scanning electron microscope. The bacterial $P$. acnes cells treated with 4xMIC stem bark ethanol extracts were compared with untreated cells, the treated cells appeared to be shrinking and there was a degradation of the cellular membrane as shown in Figure 2.

The cellular membrane of the Propionibacterium sp contains mucopeptide components such as glutamic acid, alanine, diaminopimelic acid, muramic acid and glucosamine, also minerals. ${ }^{23}$ The other research has studied about the cellular membrane of spesies Propionibacterium acnes, explained that these cellular membrane contains acidic polysaccharide consisting of neutral sugars and amino sugars, without phosphorous. ${ }^{24}$ These may explained the phenolic such as flavonoid, chalcone, stilbene compounds with many hydroxyl groups could diffuse through the microbial membrane, and also the hydroxyl may attached to an aromatic ring was required for antibacterial activity. ${ }^{25}$ Thus, antibacterial activity and membrane interference supports the theory that flavonoids also may demonstrate antibacterial activity by reducing membrane fluidity of 
Table 1: The Phytochemical Screening of Crude Drugs, Ethanol Extract And Stem Barks Fraction

\begin{tabular}{|c|c|c|c|c|c|c|}
\hline \multirow{2}{*}{ Compound group } & \multicolumn{3}{|c|}{ Crude drugs } & \multicolumn{3}{|c|}{ Ethanol extract } \\
\hline & Stem bark & Fruit & Leaves & Stem bark & Fruit & Leaves \\
\hline Alkaloid & - & - & - & - & - & - \\
\hline Flavonoid & + & + & + & + & + & + \\
\hline Tannin & + & + & + & + & + & + \\
\hline Monoterpene & + & + & - & + & + & + \\
\hline Sesquiterpene & + & + & - & + & + & - \\
\hline Steroid & - & - & - & - & - & - \\
\hline Triterpenoid & - & - & - & - & - & - \\
\hline Quinone & + & + & + & + & + & + \\
\hline Saponin & + & - & - & - & - & - \\
\hline Phenolic & + & + & - & + & + & - \\
\hline
\end{tabular}

Note: + = detected, - = not detected

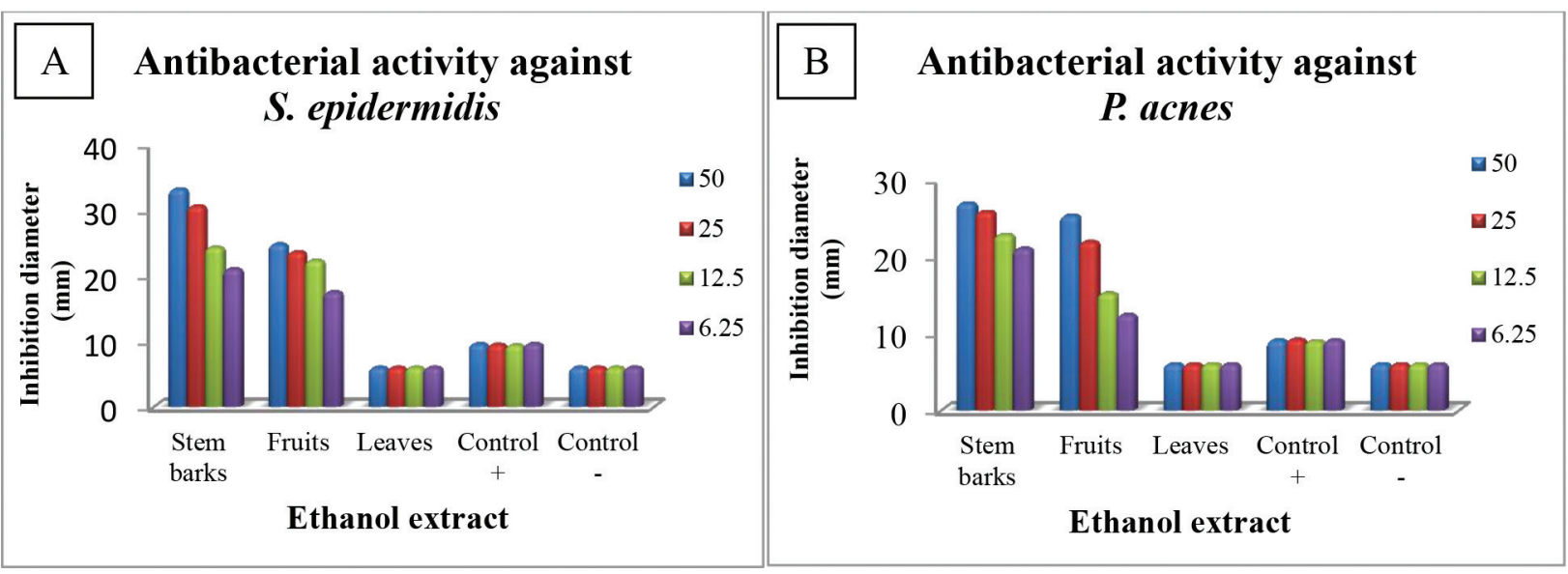

Graphic 1: Inhibition zone (diameter in $\mathrm{mm}$ ) of stem barks, fruits, leaves of Morus nigra against (A) S. epidermidis, and (B) P. acnes. Note: Perforator: 6 mm, Control (-):1\% v/v DMSO as solvent, Control (+): Clindamycin 50 $\mathrm{gg} / \mathrm{ml}$
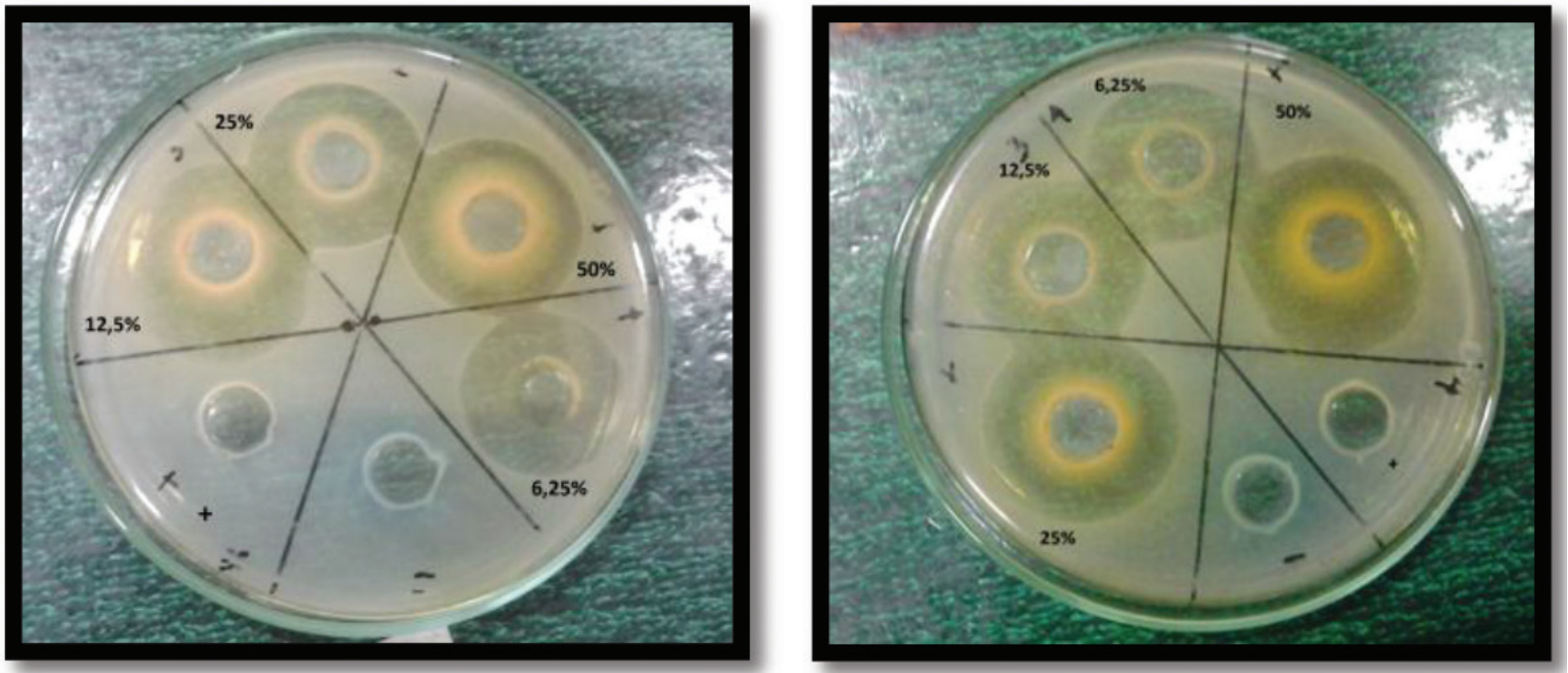

Figure 1: Inhibition zone of stem barks against (I) S. epidermidis, and (II) P. acnes. 

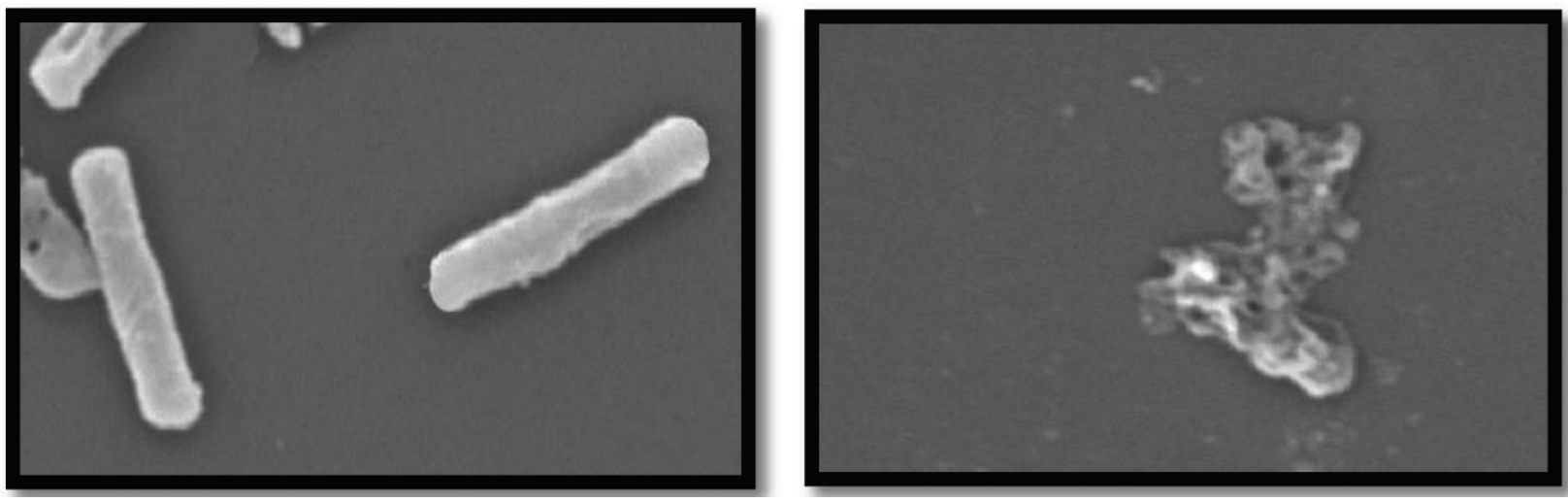

Figure 2: Propionibacterium acnes morphological cellular in scale 7500x (a) untreated, (b) bacteria treated with stem bark ethanol extract $4 \times$ MIC.

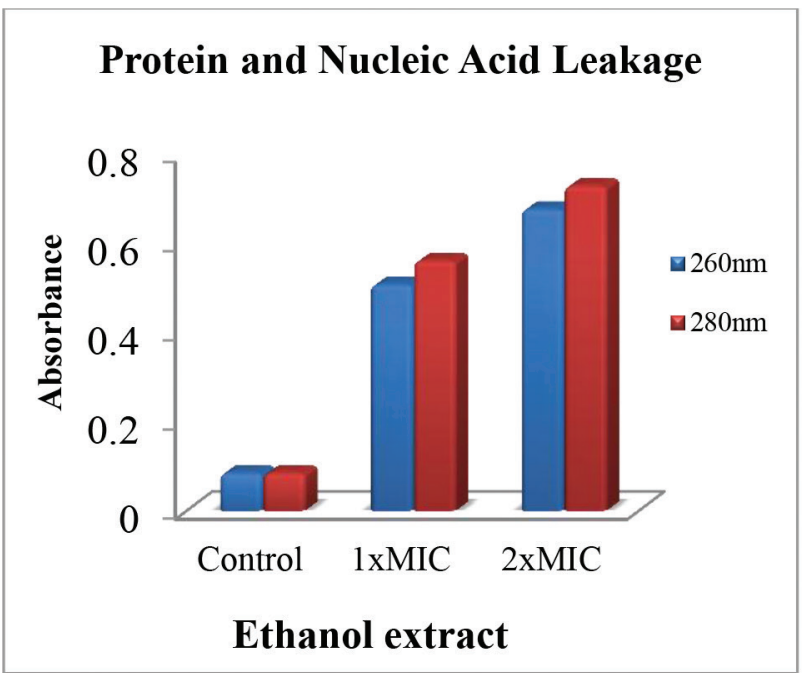

Graphic 2: Nucleic acid $(260 \mathrm{~nm})$ and protein $(280 \mathrm{~nm})$ leakage with 1 XMIC and 2xMIC of black mulberry stem bark ethanol extract against $P$. acnes.

bacterial cells and causing cell fluid imbalance (Graphic 2 and Graphic 3). ${ }^{26}$ According Khalid researched, the total phenolic contents of fresh mulberry juice about $2050 \mu \mathrm{g} / \mathrm{g}$ as gallic acid equivalent (GAE) (Khalid, Fawad, and Ahmed 2011)the fresh juice of black mulberry (Morus nigra). The black mulberry especially fruit and stem bark has excellent activities as antimicrobial agent. ${ }^{29}$

\section{CONCLUSION}

The stem bark and fruit of Morus nigra or black mulberry were found to be potentially as the source of herbal cosmetic such as in acne treatment. This study showed that the mode of action of the stem bark ethanol extract was related to the damaged of bacterial cell wall.

\section{ACKNOWLEDGEMENT}

We would like to thank to the Research Fund 2017 of the Ministry of Research, Technology and Higher Education of the Republic of Indonesia for funding and supporting on this research. The author also thank to The Indonesian Institute of Science (LIPI) Bogor, and The Central Laboratory of Universitas Padjadjaran for supporting the instruments.

\section{CONFLICT OF INTEREST}

The authors declare that there is no conflict of interest, financial, or otherwise regarding the publication of this paper.

\section{Ion $\mathrm{Ca}^{2+}$ and $\mathrm{K}^{+}$Leakage}

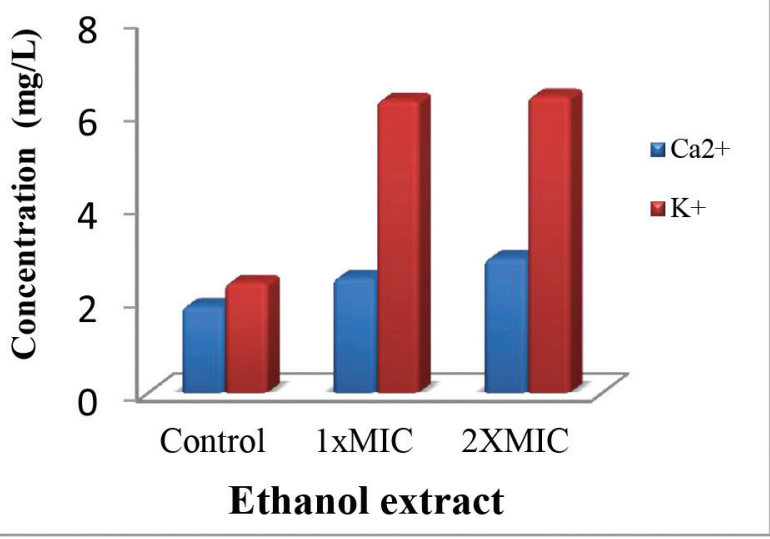

Graphic 3: Absorbance of ion calcium $\left(\mathrm{Ca}^{2+}\right)$ and Kalium $\left(\mathrm{K}^{+}\right)$with 1xMIC and 2x MIC of black mulberry stem bark ethanol extract against $P$. acnes.

\section{ABBREVIATIONS USED}

MIC: Minimal Inhibitory Concentration; MHA: Mueller Hinton Agar; MHB: Mueller Hinton Broth; CFU: Colony Forming Units, DMSO: Dimethyl Sulfoxide.

\section{REFERENCES}

1. Chomnawang MT, Surassmo S, Nukoolkarn VS, Gritsanapan W. Antimicrobial effects of Thai medicinal plants against acne-inducing bacteria. J Ethnopharmacol. 2005;101(1-3):330-3. doi:10.1016/j.jep.2005.04.038.

2. Khurram M, Khan MA, Hameed A, Abbas N, Qayum A, Inayat H. Antibacteria activities of Dodonaea viscosa using contact bioautography technique. Molecules. 2009;14(3):1332-41. doi:10.3390/molecules14031332.

3. Ferlinahayati, Hakim EH, Syah YM, et al. Senyawa Morusin dari Tumbuhan Murbei Hitam ( Morus nigra ). J Penelit Sains. 2012;15(2):70-73.

4. Mazimba O, Majinda RRT, Motlhanka D. Antioxidant and antibacterial constituents from Morus nigra. African J Pharm Pharmacol. 2011;5(6):751-4 doi:10.5897/AJPP11.260.

5. Tsuduki T, Kikuchi I, Kimura T, Nakagawa K, Miyazawa T. Intake of mulberry 1-deoxynojirimycin prevents diet-induced obesity through increases in adiponectin in mice. Food Chem. 2013;139(1-4):16-23. doi:10.1016/j.foodchem.2013.02.025.

6. Almeida JRG S, Souza GR, Araujo EC, et al. Medicinal plants and natural compounds from the genus Morus (Moraceae) with hypoglycemic activity: a review. Sect Title Pharmacol. 2012:189-206. doi:10.5772/53145.

7. Zafar MS, Muhammad F, Javed I, Akhtar M, Khaliq T, Aslam B. White Mulberry (Morus alba): A Pharmacological Evaluations Account. Brief Phytochemical and 2013:15(3):612-20.

8. Fukai T, Kaitou K, Terada S. Antimicrobial activity of 2-arylbenzofurans from 
Morus species against methicillin-resistant Staphylococcus aureus. Fitoterapia 2005;76(7-8):708-11. doi:10.1016/j.fitote.2005.06.012.

9. Eo HJ, Park JH, Park GH, et al. Anti-inflammatory and anti-cancer activity of mulberry (Morus alba L.) root bark. Bio Med Central Complement Altern Med. 2014;14(1):200. doi:10.1186/1472-6882-14-200.

10. Yigit D, Yigit N. Antibacterial activity of black mulberry (Morus nigra) fruits and leaves. Erzincan Univ J Sci Technol. 2009.

11. Budiman A, Aulifa DL, Kusuma ASW, Sulastri A. Antibacterial and Antioxidant Activity of Black Mulberry ( Morus nigra I.) Extract for Acne Treatment. Pharmacogn J. 2017;9(5):611-4.

12. Niyomkam P, Kaewbumrung S, Kaewnpparat S, Panichayupakaranant P. Antibacterial activity of Thai herbal extracts on acne involved microorganism. Pharm Biol. 2010;48(4):375-80. doi:10.3109/13880200903150443.

13. Klan A, Jer B, Smole S. Evaluation of diffusion and dilution methods to determine the antibacterial activity of plant extracts. 2010:81:121-6. doi:10.1016/j.mimet.2010.02.004

14. Farnsworth NR. Pharmaceutical Sciences. J Pharm Sci. 1966;55(3):225-76.

15. Budiman A, Aulifa DL, Kusuma ASW, Kurniawan IS, Sulastri A. Peel-off gel formulation from black mulberries (Morus nigra) extract as anti-acne mask. Natl J Physiol Pharm Pharmacol. 2017;7(9):1-8. doi:http://dx.doi.org/10.5455/ njppp.2017.7.0413123052017.

16. Rahim ZHA, Thurairajah N. Scanning Electron Microscopic study of Piper betle $L$. leaves extract effect against Streptococcus mutans ATCC 25175. J Appl Oral Sci. 2011;19(2):137-46. doi:10.1590/S1678-77572011000200010.

17. Park KM, You JS, Lee HY, Baek NI, Hwang JK. Kuwanon G: An antibacterial agent from the root bark of Morus alba against oral pathogens. J Ethnopharmacol. 2003;84(2-3):181-5. doi:10.1016/S0378-8741(02)00318-5.

18. Azifitria, Aziz S, Chairul. Antibacterial Activity of Ethanolic Extract of Leaves and Bulbs of Crinum asiaticum L. Against Acne-inducing Bacteria. Indones J Pharm. 2010;21(4):236-41.

19. Jin Q, Yang J, Ma L, Wen D, Chen F, Li J. Identification of polyphenols in mulberry (genus Morus) cultivars by liquid chromatography with time-of-flight mass spectrometer. J Food Compos Anal. 2017;63:55-64. doi:10.1016/j.jfca.2017.07.005

20. Kim YJ, Sohn MJ, Kim WG. Chalcomoracin and moracin C, new inhibitors of Staphylococcus aureus enoyl-acyl carrier protein reductase from Morus alba. Biol Pharm Bull. 2012;35(5):791-5. doi:10.1248/bpb.35.791.

21. Qin C, Li Y, Niu W, Ding Y, Zhang R, Shang X. Analysis and characterisation of anthocyanins in mulberry fruit. Czech J Food Sci. 2010;28(2):117-26.

22. Mann CM, Markham JL. A new method for determining the minimum inhibitory concentration of essential oils. 1998;84(4):538-44. (1994).

23. Allsop J, Work E. Cell walls of Propionibacterium species: fractionation and composition. Biochem. J. 1963:87(3):512-9. http://www.pubmedcentral.nih gov/articlerender.fcgi ?artid=1201991 andtool=pmcentrezandrendertype $=$ abstr act.

24. Nagaoka M, Uchikawa K, Fujii H, Sekikawa I. Structure of Acidic Polysaccharide acnes Strain from Cell Wall of Propionibacterium hydrolysis The heat-killed cells of Propionibacterium acnes ( $\mathrm{P}$. acnes ) have been widely studied as an immuno potentiator and immunotherapeutic agent for can cer in expe. J Biochem. 1985;97(6):1669-78

25. Shapiro S, Guggenheim B. QSAR Inhibition of Oral Bacteria by Phenolic Compounds . §. Symp A Q J Mod Foreign Lit. 1998;17(July 1997):327-37.

26. Shashank K, Abhay K. Review Article Chemistry and Biological Activities of Flavonoids: An Overview. Sci World J. 2013;4(2):32-48

27. Khalid N, Fawad SA, Ahmed I. Antimicrobial Activity, Phytochemical Profile and Trace Minerals of Black Mulberry (Morus nigra L.) Fresh Juice. Pak J Bot. 2011:43(May 2016):91-6.

28. Nohynek LJ, Alakomi HL, Kähkönen MP, et al. Berry phenolics: antimicrobial properties and mechanisms of action against severe human pathogens. Nutr Cancer. 2006;54(1):18-32. doi:10.1207/s15327914nc54014.

29. Kumar RV, Chauhan S. Mulberry:Life enhancer. J Med Plants Res. 2008;2(10):271-8.
GRAPHICAL ABSTRACT

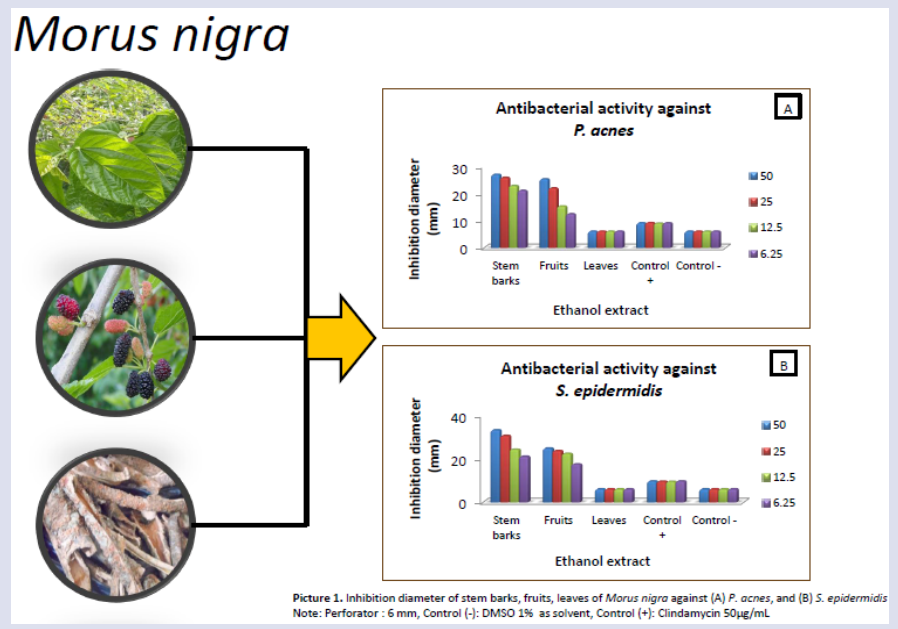

\section{ABOUT AUTHORS}

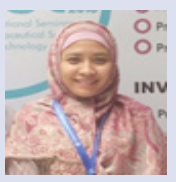

Diah Lia Aulifa is a lecturer in Sekolah Tinggi Farmasi Indonesia (Indonesian School of Pharmacy), Bandung-Indonesia, in Pharmaceutical Biology Department. Develop work in Phytochemistry and Phytotherapy from plants.

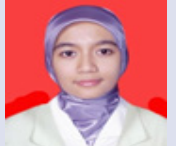

Sani Nurlaela Fitriansyah is a lecturer in Sekolah Tinggi Farmasi Indonesia (Indonesian School of Pharmacy), Bandung-Indonesia, in Pharmaceutical Biology Department. Specialization: Pharmacognosy and Natural Product Standardization.

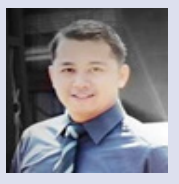

Seno Aulia Ardiansyah a lecturer in Sekolah Tinggi Farmasi Indonesia (Indonesian School of Pharmacy), Bandung-Indonesia, in Pharmacology Department. Current research interests are Microbiology and Pharmacology.

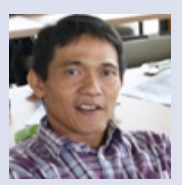

Diki Prayugo Wibowo is a lecturer in Sekolah Tinggi Farmasi Indonesia (Indonesian School of Pharmacy), Bandung-Indonesia, in Pharmaceutical Biology Department, in the area concentration Phytochemistry and Microbiology.

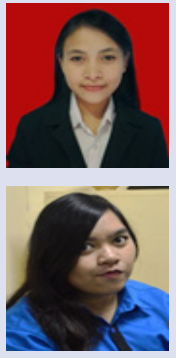

Yolanda Armiliani Julata is an undergraduate student of the Pharmacy Course, Sekolah Tinggi Farmasi Indonesia (Indonesian School of Pharmacy), Bandung-Indonesia.

Desty Santi Christy is an undergraduate student of the Pharmacy Course, Sekolah Tinggi Farmasi Indonesia (Indonesian School of Pharmacy), Bandung-Indonesia.

Cite this article: Aulifa DL, Fitriansyah SN, Ardiansyah SA, Wibowo DP, Julata YA, Christy DS. Phytochemical Screening, Antibacterial Activity, and Mode of Action on Morus nigra. Pharmacog J. 2018;10(1):167-71. 